medRxiv preprint doi: https://doi.org/10.1101/2020.08.22.20179754; this version posted August 25, 2020. The copyright holder for this preprint (which was not certified by peer review) is the author/funder, who has granted medRxiv a license to display the preprint in perpetuity.

All rights reserved. No reuse allowed without permission.

\title{
Monitoring COVID-19 transmission risks by RT-PCR tracing of droplets in hospital and
} living environments

\author{
Andrea Piana $^{\mathrm{a}}$, Maria Eugenia Colucci ${ }^{\mathrm{b}}$, Federica Valeriani ${ }^{\mathrm{c}}$, Adriano Marcolongo ${ }^{\mathrm{d}}$, Giovanni
}

Sotgiu $^{\mathrm{a}}$, Cesira Pasquarella ${ }^{\mathrm{b}}$, Lory Marika Margaruccic ${ }^{\mathrm{c}}$, Andrea Petrucca ${ }^{\mathrm{d}}$, Gianluca

Gianfranceschi $^{\mathrm{c}}$, Sergio Babudieri ${ }^{\mathrm{a}}$, Pietro Vitali ${ }^{\mathrm{b}}$, Giuseppe Dốrmo ${ }^{\mathrm{e}}$, Assunta Bizzarro ${ }^{\mathrm{b}}$, Flavio

De Maio $^{\mathrm{f}}$, Matteo Vitali ${ }^{\mathrm{g}}$, Antonio Azara ${ }^{\mathrm{a}}$, Ferdinando Romano ${ }^{\mathrm{g}}$, Maurizio Simmaco ${ }^{\mathrm{e}}$, Vincenzo

Romano Spica ${ }^{c^{*}}$

a Department of Medical, Surgical and Experimental Sciences, University of Sassari, Viale San Pietro, 43, 07100 Sassari, Italy. (piana@uniss.it; gsotgiu@uniss.it; babuder@uniss.it, azara@uniss.it)

b Department of Medicine and Surgery, University Hospital, University of Parma, Via Gramsci, 14, 43126, Parma, Italy (cesiraisabellamaria.pasquarella@unipr.it; mariaeugenia.colucci@unipr.it; assunta.bizzarro@unipr.it; pvitali@ao.pr.it)

c Department of Movement, Human and Health Sciences, Unit of Public Health-Laboratory of Epidemiology and Biotechnologies, University of Rome ñForo Italicoò, Piazza Lauro de Bosis 6, 00135 Rome, Italy (vincenzo.romanospica@uniroma4.it; federica.valeriani@uniroma4.it; 1.margarucci@studenti.uniroma4.it; gianluca.gianfranceschi@uniroma4.it)

d SantôAndrea Hospital, Sapienza University of Rome, Rome, Italy (maurizio.simmaco@uniroma1.it; andrea_petrucca@yahoo.com; marcolongo@ospedalesantandrea.it)

e Department of Surgery, Sapienza University of Rome, Rome, Italy (giuseppe.dermo@uniroma1.it)

f Dipartimento di Scienze biotecnologiche di base, cliniche intensivologiche e perioperatorie $̈$ i Sezione di Microbiologia, Università Cattolica del Sacro Cuore, Rome, Italy, (flavio.demaio@unicatt.it)

g Department of Public Health and Infectious Diseases, University of Rome La Sapienza, Rome, Italy (matteo.vitali@uniroma1.it; ferdinando.romano@uniroma1.it)

*Corresponding: Vincenzo Romano Spica; Laboratory of Department of Movement, Human and Health Sciences; University of Rome ñForo Italicoò, Piazza Lauro De Bosis 6, 00135 Rome, Italy, E-mail: vincenzo.romanospica@uniroma4.it

Keywords: SARS-CoV-2; Environmental contamination; Fomite; Droplets; Biological fluids; Microbiota.

Running: COVID-19 and droplets contamination 
medRxiv preprint doi: https://doi.org/10.1101/2020.08.22.20179754; this version posted August 25, 2020. The copyright holder for this preprint (which was not certified by peer review) is the author/funder, who has granted medRxiv a license to display the preprint in perpetuity.

All rights reserved. No reuse allowed without permission.

\section{ABSTRACT}

34 SARS-CoV-2 environmental contamination occurs through droplets and biological fluids released 35 in the surroundings from patients or asymptomatic carriers. Surfaces and objects contaminated by saliva or nose secretions represent a risk for indirect transmission of COVID-19. We assayed

37 surfaces from hospital and living spaces to identify the presence of viral RNA and the spread of fomites in the environment. Anthropic contamination by droplets and biological fluids was monitored by detecting the microbiota signature using multiplex RT-PCR on selected species and massive sequencing on $16 \mathrm{~S}$-amplicons.

A total of 92 samples (flocked swab) were collected from critical areas during the pandemic, including indoor (3 hospitals and 3 public buildings) and outdoor surfaces exposed to anthropic contamination (handles and handrails, playgrounds). Traces of biological fluids were frequently detected in spaces open to the public and on objects that are touched with the hands $(>80 \%)$. However, viral RNA was not detected in hospital wards or other indoor and outdoor surfaces either in the air system of a COVID-hospital, but only in the surroundings of an infected patient, in consistent association with droplets traces and fomites. Handled objects accumulated the highest level of multiple contaminations by saliva, nose secretions and faecal traces, further supporting the priority role of handwashing in prevention. In conclusion, anthropic contamination by droplets and biological fluids is widespread in spaces open to the public and can be traced by RT-PCR. Monitoring fomites can support evaluation of 
medRxiv preprint doi: https://doi.org/10.1101/2020.08.22.20179754; this version posted August 25, 2020. The copyright holder for this preprint (which was not certified by peer review) is the author/funder, who has granted medRxiv a license to display the preprint in perpetuity.

All rights reserved. No reuse allowed without permission.

\section{Importance}

59 Several studies searched for SARS-CoV-2 in the environment because saliva and nasopharyngeal

60 droplets can land on objects and surfaces creating fomites. However, the ideal indicator would be

61 the detection of the biofluid. This approach was not yet considered, but follows a traditional

62 principle in hygiene, using indicators rather than pathogens. We searched for viral RNA but also

63 for droplets on surfaces at risk. For the first time, we propose to monitor droplets thorugh their

64 microbiota, by RT-PCR or NGS.

65 Even if performed during the pandemic, SARS-CoV-2 wasnâ largely spread on surfaces, unless

66 in proximity of an infectious patient. However, anthropic contamination was frequently at high

67 level, suggesting a putative marker for indirect transmission and risk assessment. Moreover, all

68 SARS-CoV-2- contaminated surfaces showed the dropletsômicrobiota.

69 Fomites detection may have an impact on public health, supporting prevention of indirect

70 transmission also for other communicable diseases such as Flu and Flu-like infections.

71

72

73 
medRxiv preprint doi: https://doi.org/10.1101/2020.08.22.20179754; this version posted August 25, 2020. The copyright holder for this preprint (which was not certified by peer review) is the author/funder, who has granted medRxiv a license to display the preprint in perpetuity. All rights reserved. No reuse allowed without permission.

77

78

79

80

81

Monitoring SARS-CoV-2 transmission risk by tracing droplets and fomites using RT-PCR

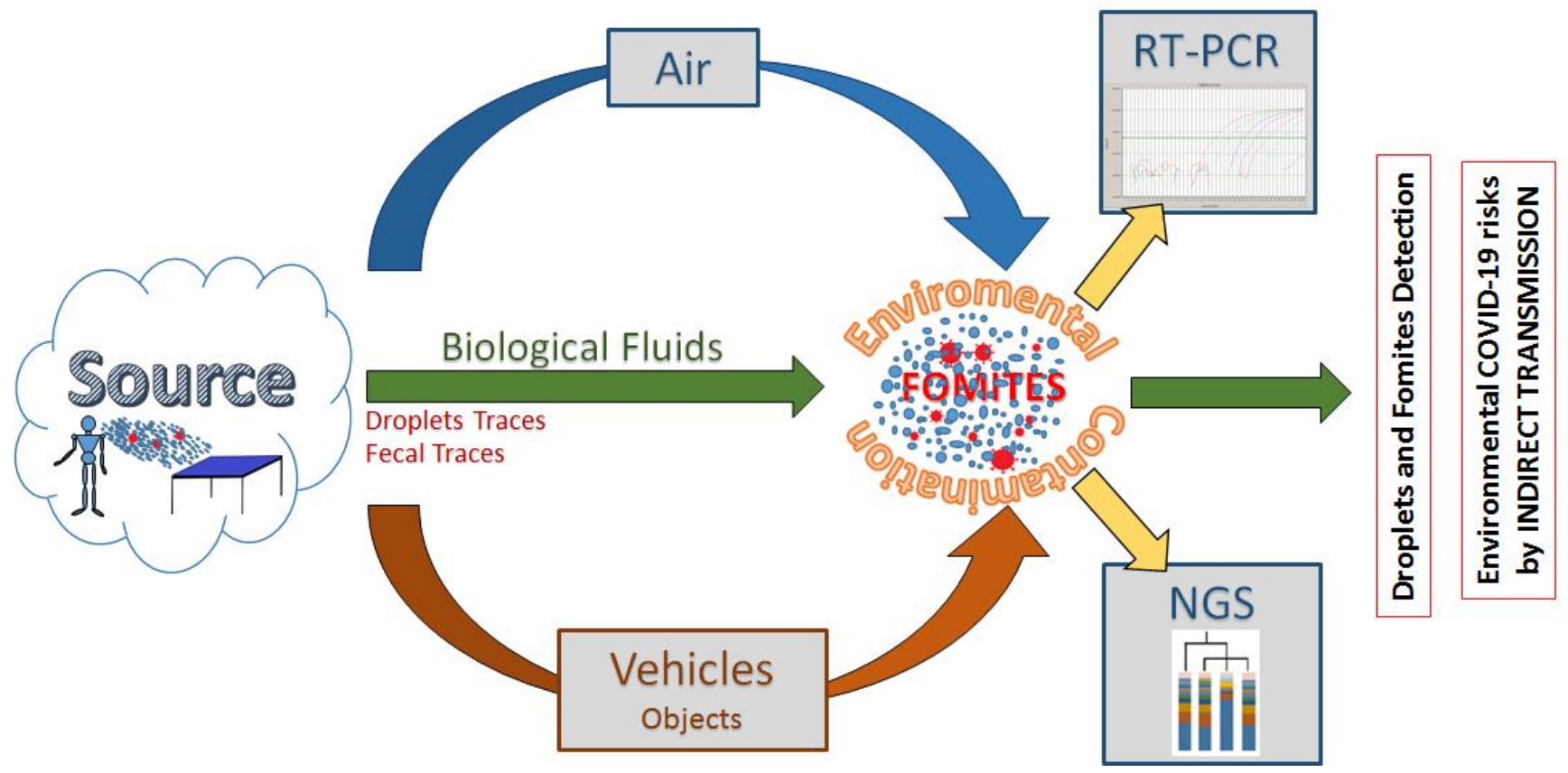


medRxiv preprint doi: https://doi.org/10.1101/2020.08.22.20179754; this version posted August 25, 2020. The copyright holder for this preprint (which was not certified by peer review) is the author/funder, who has granted medRxiv a license to display the preprint in perpetuity.

All rights reserved. No reuse allowed without permission.

84

85

86

87

88

89

90

91

92

93

94

95

96

97

98

99

100

101

102

103

104

105

\section{Introduction}

The ongoing pandemic of coronavirus disease 2019 (COVID-19) is thought to have spread mainly through a direct route of transmission: by person to person close contact and inhalation of virusladen liquid droplets (WHO, 2020; Stadnytskyi et al., 2020; Somsen et al., 2020; Liu et al., 2020; NCIRD, 2020; Asadi et al, 2020). However, it is also recognised that Severe Acute Respiratory Syndrome Coronavirus 2 (SARS-CoV-2) can follow an indirect route of transmission through environmental contamination of objects and surfaces, being carried by biological fluids such as saliva, nose secretions, and feces, in which viral RNA was consistently detected (Van Doremalen, et al., 2020; Chia et al., 2020; Guo, et al., 2020; Cheng et al., 2020; Ong et al., 2020; Lv et al., 2020; Razzini et al., 2020; Li et al., 2020; Chen et al., 2020; Foladori et al., 2020). Respiratory droplets (aerodynamic diameter ranging between $>5$ and $10 \mu \mathrm{m}$ ) and droplet nuclei or aerosols (Ò $5 \mu \mathrm{m}$ ) from a patient or an asymptomatic subject can reach directly the mouth, nose or eyes of a susceptible person, but can also land in the surroundings, creating contaminated surfaces, namely fomites (WHO, 2014; Wei et al., 2020; Otter et al., 2016; Al Huraimel et al., 2020). The risk of an indirect transmission through contaminated surfaces is related to the capability of the coronavirus to survive on different matrices under different conditions, persisting from hours to days, especially in indoor environments (Eslami and Jalili. 2020; Kampf et al., 2020; Hung et al., 2020). The question of evaluating the level of environmental contamination is important not only during outbreaks and the epidemic peak, but also during the transition phases, when asymptomatic infected carriers may release the virus in the environment by talking, coughing, sneezing, touching objects and consequently spreading contaminated biofluids (including saliva and nose secretions, faecal traces or droplets) (Kampf et al., 2020; Hung et al., 2020; Wu et al., 2020). This issue has already been considered in higher-risk environments such as hospitals and public areas, where 
medRxiv preprint doi: https://doi.org/10.1101/2020.08.22.20179754; this version posted August 25, 2020. The copyright holder for this preprint (which was not certified by peer review) is the author/funder, who has granted medRxiv a license to display the preprint in perpetuity.

All rights reserved. No reuse allowed without permission.

106

107

108

109

110

111

112

113

114

115

116

117

118

119

120

121

122

123

124

125

126

127

128

SARS-CoV-2 was clearly detected in several studies, even when surveillance and sanitation were accurately performed (Wu et al., 2020; Wang et al. 2020).

Finally, when approaching the question of the presence of SARS-CoV-2 in the environment, we need to consider that the pathogen is conveyed by biological fluids. Therefore, the possibility of detecting fomites and biological fluids in the environment becomes both a potential marker of hygiene levels, and also a candidate indicator for indirect COVID-19 transmission risks. Starting from this working hypothesis, we surveyed hospitals and public buildings not simply for the presence of SARS-CoV-2, but also for the presence of droplets, fomites and anthropic contaminations, by searching traces of the microbiota signature of their own biological fluids of origin. To address this issue, a dedicated set of primers and probes was combined to detect different biological fluids based on multiplex reactions in real-time PCR (RT-PCR), following a strategy initially developed for forensic studies and hospital hygiene (Giampaoli et al., 2012; Giampaoli et al., 2014; Valeriani et al., 2016; Valeriani et al., 2018a; Yao et al., 2020). Thus, a same general approach based on RT-PCR was considered to test both the viral RNA by standard procedures and the DNA from fomites by microbiota signature. The general principle is based on the amplification of genes from at least one representative bacterial component of the biological fluid, e.g. amplifying bacterial genes from $E$. salivarius and $S$. mutans for targeting saliva, or Corynebacterium for nose secretions, or E. faecalis and Bacteroides for evaluating the presence of faecal traces, as previously shown (Esberg et al., 2020; Liu et al., 2020; Charles et al., 2019; Proctor et al., 2019; Lloyd-Price, J et al., 2016). This approach can be confirmed by next generation sequencing (NGS), analysing the whole microflora DNA (mfDNA) as sampled with environmental swabs on indoor and outdoor surfaces (Slatko et al., 2018; Valeriani et al., 2018b; Valeriani et al., 2018c; Valeriani et al., 2019; Mucci et al., 2020). 
medRxiv preprint doi: https://doi.org/10.1101/2020.08.22.20179754; this version posted August 25, 2020. The copyright holder for this preprint (which was not certified by peer review) is the author/funder, who has granted medRxiv a license to display the preprint in perpetuity.

All rights reserved. No reuse allowed without permission.

129

130

131

132

133

134

135

136

137

138

139

140

141

142

143

144

145

146

147

148

149

150

151

152

The overall aim of this study was to search for both SARS-CoV-2 and fomites in hospitals and public buildings, to evaluate the possibility of monitoring by RT-PCR fomites and biofluid contamination, as a novel indicator of hygiene as well as a candidate marker for indirect transmission risks for COVID-19.

\section{Materials and Methods}

\subsection{Sampling and experimental design}

Surfaces at risk for the presence of biological fluids and the transmission of COVID-19 were sampled from different settings, both in indoor and outdoor areas. Environmental samples (n=94) were collected after the epidemic peak in Italy (May-June 2020). We sampled indoor surfaces from three COVID-reference hospitals in three Italian regions (Parma, Emilia-Romagna; Sassari, Sardinia; Rome, Lazio); buildings open to public use (1 office, 1 fast food, 1 church); outdoor areas; and used handkerchiefs with nasopharyngeal secretions. Samples were tested for SARSCoV-2 RNA, whereas anthropic contamination was assessed searching for biological fluids of nose, mouth, gut through their microbiota traces by RT-PCR and/or NGS (Table 1).

\subsection{Sampling collection}

Surface sampling was carried out after their use and prolonged exposure to human presence ( $>4 \mathrm{~h})$. Following standard protocols, FLOGSwabs and CITOSSWAB were used and soaked into a buffer solution in a volume of $400 \mu 1$ of UTM-RM transport medium (Copan Diagnostics Inc., Murrieta, CA, USA). The nasopharyngeal secretions were collected on handkerchiefs with swabs (4N6FLOQSwabs, Copan Diagnostics Inc., Murrieta, CA, USA). All specimens were refrigerated at $4{ }^{\circ} \mathrm{C}$ if testing could postpone in the following days. 
medRxiv preprint doi: https://doi.org/10.1101/2020.08.22.20179754; this version posted August 25, 2020. The copyright holder for this preprint (which was not certified by peer review) is the author/funder, who has granted medRxiv a license to display the preprint in perpetuity.

All rights reserved. No reuse allowed without permission.

\subsection{SARS-CoV-2 detection}

155

156

157

158

159

160

161

162

163

164

165

166

167

168

169

170

171

172

173

174

175

176

All samples in UTM were heat inactivated at $56^{\circ} \mathrm{C}$ for 5 minutes to reduce the risk of accidental transmission of SARS-CoV-2 to laboratory personnel. Nucleic acids were purified and extracted using the eMag automated nucleic acid sample extraction system (bioMérieux, Marcy lâEtoile, France). Briefly, total nucleic acids were extracted from UTM using an input sample volume of $200 \mu \mathrm{l}$ into 2,000 $\mu \mathrm{l}$ of easyMag lysis buffer using B protocol to a final eluted volume of purified nucleic acids of $50 \mu \mathrm{l}$. TaqPath 1-step reverse transcriptase quantitative PCR (RT-qPCR) master mix (Life Technologies, Frederick, MD) and the 2019- nCoV CDC EUA kit (Integrated DNA Technologies, Coralville, IA) were used for target detection $(C D C, 2020)$. Molecular detection of SARS-CoV-2 RNA was carried out by rRT-PCR, using primers and probes related to the E gene, with a detection limit of 5.2 copies of RNA/reaction (Corman V. 2019). Samples were analyzed in Sassari and Parma with the Allplex 2019-nCoV assay (Seegene, Seoul, South Korea) and in Rome with the Detection Kit for 2019 Novel Coronavirus (2019-nCoV) RNA (PCR-Fluorescence Probing) (Daan Gene Co., Ltd of Sun Yat-University, Guangzhou, Guandong, China) for the confirmation of the results. The Allplex 2019-nCoV assay was designed for amplifying three viral targets: the E gene (subgenus Sarbecovirus), the N, and the RdRP genes (Farfour, 2020). The Detection Kit for 2019 Novel Coronavirus (2019-nCoV) RNA (PCR-Fluorescence Probing) is a CE-marked RT-PCR assay which simultaneously detects the viral nucleocapsid N and Orflab genes. Afterward, $5 \mu 1$ of eluted RNA samples in a total volume of $25 \mu 1$ were RT-PCR amplified on Biorad CFX96 real-time system. In each round of extraction and amplification, positive and negative control samples (supplied by the manufacturer) were included. The interpretation criteria were the following: 1) positive signals detected in ORF1ab and $\mathrm{N}$ genes with a cycle threshold (Ct) values Ò+0 were considered positive for SARS-CoV-2 RNA; 2) positive signals in only one 
medRxiv preprint doi: https://doi.org/10.1101/2020.08.22.20179754; this version posted August 25, 2020. The copyright holder for this preprint (which was not certified by peer review) is the author/funder, who has granted medRxiv a license to display the preprint in perpetuity.

All rights reserved. No reuse allowed without permission.

177 gene (N or Orf1ab) with a $\mathrm{Ct}$ values Ò+0 were considered inconclusive; and 3) no fluorescent

178 signals or over the 40th $\mathrm{Ct}$ in ORF1ab and $\mathrm{N}$ genes were considered not specific and reported as

179 negative for SARS-CoV-2 RNA. The declared LoD is 500 RNA copies/ml.

\subsection{DNA extraction}

182

183

184

185

186

187

188

189

190

191

192

193

194

195

196

197

198

An aliquot of COPAN UTM-RM transport medium (about $300 \mathrm{gL}$ ) was centrifugated at $16000 \mathrm{~g}$ for 10 minutes and the pellet was manually disaggregated with a pestle after adding glass beads (Sigma-Aldrich, St Louis, MO) and lysed in 200 عL lysozyme solution, RNase A treated, and proteinase K digested according to the GenElute Bacterial Genomic DNA Kit (Sigma Aldrich, St Louis, USA). Finally, DNA elution was performed in 60 LL elution solution (10 mM tris(hydroxymethyl)aminomethane-hydrochloride and $0.5 \mathrm{mM}$ ethylene diamine tetra acetic acid, $\mathrm{pH}$ 9.0). For pharyngeal biofluids and fomites samples, each swab was inserted into the semipermeable NAO Baskets and broken inside at the breakpoint. Approximately $200 \varepsilon \mathrm{L}$ lysozyme solution $(20 \mathrm{mg} / \mathrm{mL}$ Lisozima, $20 \mathrm{mM}$ tris[hydroxymethyl]aminomethanehydrochloride at $\mathrm{pH} 8,2 \mathrm{mM}$ ethylenediaminetetraacetic acid, and 1.2\%TritonX-100; Sigma Aldrich, St Louis, USA) were added into the NAO Baskets and incubated a $37^{\circ} \mathrm{C}$ for 30 minutes. Then, 20 عL proteinase $\mathrm{K}$ and $400 \varepsilon \mathrm{L}$ buffer AL were added and the sample was centrifuged at $10,000 \times \mathrm{g}$ for 1 minute, allowing the elution of the digestion solution. After incubation at $56^{\circ} \mathrm{C}$ for 10 minutes and addition of $400 \varepsilon \mathrm{L}$ ethanol, the washing step and DNA puriýcation were performed in accordance with the manufacturerôs instructions. DNA elution was completed in 60 عL elution solution $\quad(10 \quad \mathrm{mM} \quad$ tris[hydroxymethyl]aminomethane-hydrochloride $\quad$ and $\quad 0.5 \quad \mathrm{mM}$ ethylenediaminetetraacetic acid at $\mathrm{pH}$ 9.0), as previously described (Cianfanelli et al., 2017; Valeriani et al., 2017; Valeriani et al., 2018c;). 
medRxiv preprint doi: https://doi.org/10.1101/2020.08.22.20179754; this version posted August 25, 2020. The copyright holder for this preprint (which was not certified by peer review) is the author/funder, who has granted medRxiv a license to display the preprint in perpetuity.

All rights reserved. No reuse allowed without permission.

201

202

203

204

205

206

207

208

209

210

211

212

213

214

215

216

217

218

219

220

221

222

223

224

\subsection{Analysis of mfDNA by multiplex real-time PCR and data interpretation}

Ampliýcations were combined in 4 multiplex reactions: mix Skin, for the identiýcation of Staphylococcus aureus and Staphylococcus epidermidis; mix Nasopharynx for Propionibacterium spp. and Corynebacterium spp.; Mix oralpharinx for Streptococcus salivarius and Streptococcus mutans; mix feces for Enterococcus spp and Bacteroides vulgatus (probes were labeled FAM/VIC/HEX, with the BHQ-1quencher). Primers for different bacterial indicators and optimized reaction conditions were already established, as previously described (Elshi et al., 2000; Giampaoli et al., 2012; Chung et al., 2016; Valeriani et al. 2018a; Byrd et al., 2018; Liu, Q. 2020). Briefly, amplifications were performed in a volume of $25 \varepsilon \mathrm{L}$, of which 12.5 عL JumpStart Taq ReadyMix for Quantitative PCR (Sigma Aldrich, St. Louis, MO), containing 900nM forward and reverse primers, and $250 \mathrm{nM}$ of each probe. For each mix, samples were tested in triplicate. The ampliýcations were performed using Bio-RadCFX96(Bio-Rad,Hercules, CA) programmed for 10 minutes at $95^{\circ} \mathrm{C}$ and 40 cycles of 15 seconds at $95^{\circ} \mathrm{C}$ and 1 minute at $60^{\circ} \mathrm{C}$. For each sample 11 عL template reaction was ampliýed. The PCR output was expressed as cycle threshold (CT). Positive samples were those where Ól positive indicator (CT Ò35) was found in at least 2 mixes. Conversely, a microbial indicator was considered negative when over the CT Ó39 threshold.

\subsection{S rDNA Amplicon sequencing analysis}

Libraries for NGS were prepared according to the 16S Metagenomic Sequencing Library Preparation Guide (part\# 15044223 rev A; Illumina, San Diego, CA, USA). The PCR amplicons were obtained using $\mathrm{Ba} 27 \mathrm{~F}$ and $\mathrm{Ba} 338 \mathrm{R}$ primers containing overhang adapters, as previously described (40, 41). Tagged PCR products were generated using primer pairs with unique barcodes through two-step PCR. In this strategy, target primers containing overhang adapters were used in the first PCR reaction to amplify the target gene, that product was then used in the second PCR 
medRxiv preprint doi: https://doi.org/10.1101/2020.08.22.20179754; this version posted August 25, 2020. The copyright holder for this preprint (which was not certified by peer review) is the author/funder, who has granted medRxiv a license to display the preprint in perpetuity.

All rights reserved. No reuse allowed without permission.

225

226

227

228

229

230

231

232

233

234

235

236

237

238

239

240

241

242

243

244

245

246

247

248

using primers-containing barcodes. Each amplification reaction had a total volume of $25 \varepsilon \mathrm{L}$, containing 12.5 عL of KAPA HiFi Hot Start Ready Mix (Roche, Pleasanton, CA, USA), 5 عL of each primer ( $1 \varepsilon \mathrm{M})$, and $2 \varepsilon \mathrm{L}$ of template DNA. Reactions were carried out on a Techne®TCPLUS thermocycler (VWR International, LLC, Radnor, PA, USA). Following amplification, 5 عL of PCR product from each reaction was used for agarose gel (1\%) electrophoresis to confirm amplification. The final concentration of cleaned DNA amplicon was determined using the Qubit PicoGreen dsDNA BR assay kit (Invitrogen, Grand Island, NY, USA) and validated on a Bioanalyzer DNA 1000 chip (Agilent, Santa Clara, CA, USA). Libraries were prepared using the MiSeq Reagent Kit Preparation Guide (Illumina, San Diego, CA, USA). Raw sequence data was processed using an in-house pipeline that was built on the Galaxy platform and incorporated various software tools to evaluate the quality of the raw sequence data (FASTA/Q Information tools, Mothur). All datasets were rigorously screened to remove low-quality reads (short reads >200 nt, zero-ambiguous sequences). Demultiplexing was performed to remove PhiX sequences and sort sequences; moreover, to minimize sequencing errors and ensure sequence quality, the reads were trimmed based on the sequence quality score using Btrim (an average quality score of 30 from the ends, and remove reads that are less any $200 \mathrm{bp}$ after end-trimming) (Kong, 2011). OTUs (operational taxonomic units) were clustered at a 97\% similarity level, and final OTUs were generated based on the clustering results, and taxonomic annotations of individual OTUs were based on representative sequences using RDPôs 16S Classifier 2.5. Observed OTUs were defined as observed species. A level of $97 \%$ sequence identity is often chosen as representative of a species and $95 \%$ for a genus. The sequence reads were analyzed, also, in the cloud environment BaseSpace through the $16 \mathrm{~S}$ Metagenomics app (version 1.0.1; Illumina ${ }^{\circledR)}$ : the taxonomic database used was the Illumina-curated version (May 2013 release of the Greengenes Consortium Database) (Wang et al., 2013). 
medRxiv preprint doi: https://doi.org/10.1101/2020.08.22.20179754; this version posted August 25, 2020. The copyright holder for this preprint (which was not certified by peer review) is the author/funder, who has granted medRxiv a license to display the preprint in perpetuity.

All rights reserved. No reuse allowed without permission.

\subsection{Statistical Analysis}

251 Relative abundances of community members were determined with rarefied data and summarized

252 at each taxonomic level. The proportion of the microbiome at each taxonomic rank, such as

253 phylum, order, class, family, and genus, was determined using the RDP classifier and the

254 Greengenes Database. Alpha and beta diversity were calculated using EstimateS software at a level

255 of $97 \%$ sequence similarity. Regarding alpha diversity, the Shannon index and equitability index

256 at the species level were computed (Colwell et al., 2012; Magurran, 2016). Principal component

257 analysis (PCA) was performed using the METAGENassist platform and and R (version 3.1.3,

258 www.R-project.org) with packages ñggplot2ò, ñapeò, ñpsychò and ñveganò (Arndt et al., 2012).

259 Multivariate analysis, the PCA, and partial least square-discriminant analysis (PLS-DA) were

260 performed in order to investigate the dissimilarity between groups. Feature selection was

261 performed using PLS-DA and 10-fold cross validation to tune algorithm parameters and to check

262 model validity. Dendrogram and clustering analysis were based on the Euclidean distance and

263 Wardôs method.

264

265 3. Results and discussion

2663.1 Detection of fomites by RT-PCR

267 Anthropic contamination by droplets and biofluids was detected on different environmental

268 surfaces by RT-PCR (Table 2). The presence of fomites appeared largely diffused in indoor and

269 outdoor areas exposed to human crowding or frequently touched with hands. Floors and walls were

270 less contaminated than handles or buttons. Droplets DNA traces were detected in most of surfaces

271 and almost $10 \%$ of sampled points displayed a multiple contamination from different biological 
medRxiv preprint doi: https://doi.org/10.1101/2020.08.22.20179754; this version posted August 25, 2020. The copyright holder for this preprint (which was not certified by peer review) is the author/funder, who has granted medRxiv a license to display the preprint in perpetuity.

All rights reserved. No reuse allowed without permission.

272 fluids. Correlation between selected bacterial species and biological fluids in droplets and fomites

273 was confirmed (p-value <0.01) (Table 3), supporting the effectiveness of the approach. The

274 combined action of different markers is synergic (Figure 1), allowing a reliable identification of

275 droplets and fomites. Indoor and outdoor samples showed the presence of traces from one or more

276 human biofluids, although with different intensity. Being a quantitative approach, indeed, RT-PCR

277 can provide not only a qualitative output for the presence of droplets traces, but also an indication

278 on the contamination level, allowing to set different thresholds or report CT data in the form of

279 genomic units. However, the definition of a more precise quantitative interpretation of the

280 multiplex amplification output would require a larger exploitation of the method, based on

281 different environments, monitoring purposes or expected hygiene levels. The procedure to extract

282 nucleic acid and detect anthropic contamination from environmental swabs could be automatize,

283 likewise already done for testing SARS-CoV-2 from human swabs; therefore, detection of fomites

284 by RT-PCR seems a feasible and promising approach even on a larger scale.

\subsection{SARS-CoV-2 in hospitals and public places}

287

288

289

290

291

292

SARS-CoV-2 was not detected in most of the sampling points, both indoor and outdoor. It was not found in all 15 sampling points within the air system of a COVID-19 hospital. SARS-CoV-2 RNA was detected only in one room where an infected patient was hospitalized and only in those samples collected near to the patient (one on the bed rail and one on the surface of the call button).

The stethoscope used on the patient was positive, too. The low frequency $(<4 \%)$ of positive samples in comparison with other studies (20-30\%) can be associated to differences in the sampling strategy or to a lower sensitivity of the method (Liu, Y., 2020); moreover, it depends on the epidemiological scenario when the study was carried out, at time when reopening of activities 
medRxiv preprint doi: https://doi.org/10.1101/2020.08.22.20179754; this version posted August 25, 2020. The copyright holder for this preprint (which was not certified by peer review) is the author/funder, who has granted medRxiv a license to display the preprint in perpetuity.

All rights reserved. No reuse allowed without permission.

295

296

297

298

299

300

301

302

303

304

305

306

307

308

309

310

311

312

313

314

315

316 317 highest values (35-80\%) were observe in environmental swabs collected from human

was carefully surveilled and preventive measures were strictly enforced (Pasquarella, 2020; Di Maria, 2020; Veronesi, 2020; Van Doremalen, et al., 2020; Chia et al., 2020; Guo, et al., 2020; Cheng et al., 2020; Ong et al., 2020; Lv et al., 2020; Razzini et al., 2020; Li et al., 2020; Chen et al., 2020; Foladori et al., 2020; Wei et al., 2020). From our findings, it seems that the environmental spread of SARS-CoV-2 was not widely diffused, with the only exception of the surfaces near a hospitalized infected patient.

\subsection{NGS analysis.}

The microbial signature obtained by RT-PCR was confirmed by NGS and all selected bacterial indicators were also included within the microbiota identified by high-throughput sequencing and bioinformatic analysis. RT-PCR and NGS characterized environmental samples based on their contamination patterns: by CT analysis on selected marker genes or by reads count on all $16 \mathrm{~S}$ amplicon sequences, respectively (Figures 2 and 3). DNA test can be easily performed within one day on any real time apparatus, whereas NGS within one week adapting the laboratory protocol to the high throughput sequencer and accomplishing the required bioinformatic evaluation on the obtained data. However, NGS provides the 16S rDNA sequences of all the bacterial species in the sample, so that any anthropic contamination can represent just only a minority of the resident or acquired microflora on a surface. Therefore, each selected indicator specifically amplified by RTPCR was observed by NGS, but only as a subcomponent between others (about 200-1000 species for each sample), including the unknown species (about 5-10\%). Mean values ranged from $0.24 \%$ (Bacteroides) to $5.78 \%$ (Corynebacterium). For example, Corynebacterium showed lower values $(<1 \%)$ in environmental samples exposed to multiple sources of microbial pollutions, whereas the 
medRxiv preprint doi: https://doi.org/10.1101/2020.08.22.20179754; this version posted August 25, 2020. The copyright holder for this preprint (which was not certified by peer review) is the author/funder, who has granted medRxiv a license to display the preprint in perpetuity.

All rights reserved. No reuse allowed without permission.

318

319

320

321

322

323

324

325

326

327

328

329

330

331

332

nasopharyngeal secretions, further confirming the specific role of that marker within the microbial signature of the biological fluid. Nevertheless, both methods provided similar dendrograms. The correspondence between RT-PCR and NGS was reliable: two independent SARS-CoV-2 positive samples (YH1_01 and YH1_05) collected from same patient surroundings closely gathered, whereas the sample collected from the stethoscope used on the same patient (YH1_12) segregated at a different distance, in both dendrograms. Indeed, the anthropic contaminations present on the right side of the bed (YH1_01) and on the call bottom (YH1_05) showed a similar biodiversity pattern (as also shown by the Shannon index 2.602 and 2.893, respectively), characterized by the presence of traces from different biofluids, suggesting a possible contamination through the patient right hand. Conversely, sample YH1_12 displayed microbiota traces mainly restricted to nasopharyngeal secretions and with a different biodiversity pattern (Shannon index 2.161), suggesting a possible contact of the stethoscope on the patient chest (probably contaminated after a sneeze without keeping the mask). Eventually, NGS provided a more comprehensive overview of all the environmental bacteria present on the sampled surfaces, confirming also those coming from the microbiota of human biological fluids.

\subsection{Fomites and environmental microflora}

Environmental contamination through droplets or biofluids that can convey SARS-CoV-2 represents an additional component of the complex microflora detectable on a surface. Indeed, the identification of fomites by RT-PCR analysis of selected indicators emphasizes a very specific and often minority- component of the resident or ectopic microflora. The analysis of the dataset by NGS showed not only the wide presence of fomites on several surfaces exposed to anthropic contamination, but also the inhabiting microorganisms or those from other environmental sources. 
medRxiv preprint doi: https://doi.org/10.1101/2020.08.22.20179754; this version posted August 25, 2020. The copyright holder for this preprint (which was not certified by peer review) is the author/funder, who has granted medRxiv a license to display the preprint in perpetuity.

All rights reserved. No reuse allowed without permission.

341 Samples collected from indoor and outdoor surfaces gathered independently from human biofluids

342 (Figure 5). Within the outdoor group, those with a higher anthropic contamination overlapped with 343 indoor samples, far from those where the environmental component was overwhelming.

344 Interestingly, only an outdoor sample segregated outside -and in between- of both groups: the 345 external handle of the entrance of a public building (Z_04), characterized by multiple 346 contaminations of anthropic origin overlaying the outside microflora. Other indoor samples

347 grouped together. These findings support the utility of microbiota data for tracing fomites in 348 environmental samples and can sustain risk assessment for an indirect transmission of COVID-19.

349 Nevertheless, the detection of traces of biological fluids in several environmental surfaces did not 350 predict the presence of SARS-CoV-2, unless in virus positive points, even if sampling occurred 351 during the pandemic period and in hospitals where COVID-19 patients were treated. Therefore, if 352 fomites represent a risk themselves, the possibility for a contagion relays on the presence of the 353 specific pathogen and its viability, satisfying the principles from the ancient Kochôs postulates 354 (Segre, 2013). Moreover, even if detectable through its RNA, the environmental survival of SARS355 CoV-2 depends on different indoor and outdoor factors, including sanitation, time from the release 356 of the biological fluid, exposure to agents such as humidity, temperature, air circulation and 357 sunlight (Aboubakr, 2020; Morawska, 2020; Yolitz, 2020; Ratnesar-Shumate, 2020; Biryukov, 358 2020). Therefore, viral infectivity can vary significantly between different environments and 359 detection of fomites should be considered more as a putative indicator of transmission risk levels, 360 than a danger itself. Monitoring droplets and biofluids by RT-PCR can help to prevent SARS361 CoV-2 transmission by improving environmental surveillance and enforcing hygiene and 362 sanitization procedures. 
medRxiv preprint doi: https://doi.org/10.1101/2020.08.22.20179754; this version posted August 25, 2020. The copyright holder for this preprint (which was not certified by peer review) is the author/funder, who has granted medRxiv a license to display the preprint in perpetuity.

All rights reserved. No reuse allowed without permission.

\subsection{Critical issues and limits of the study}

Even if several surfaces at risk of indirect transmission were evaluated, the study aim was not the quantification of the infectious risk. Comparisons between sampling points or buildings cannot be performed, not only for the sample size but also for the random collection from areas with a different incidence of disease. Indeed, different Italian regions were selected to avoid geographical bias, but different epidemiological burdens can affect the generalizability of the results. Therefore, we have simply reported an environmental scenario, suggesting a possible strategy to assess contaminations at risk for indirect transmission of COVID-19. Interestingly, SARS-CoV-2 positive samples were collected only in Emilia-Romagna, a region with the highest number of cases in Italy (Veronesi et al., 2020). Thus, this is not an epidemiological study aimed at comparing geographical areas or quantify a risk for a specific environment or sampled surface. Nevertheless, observed data clearly identify surfaces at risk and confirm the fundamental role played by hands. Regarding the chosen approach, RT-PCR is faster than NGS (3-5 hours vs 5-10 days), but still is not instantaneous, as other strategies aimed to detect contaminations on surfaces or medical devices (Valeriani, 2018 a; Lee, 2020).Tracing droplets and identifying biological fluids by RTPCR or NGS is specific respect to other methods based on finding organic matter without a recognition of their origin, e.g. from human secretions rather than human cells, plant, animal or bacterial debris. Therefore, detection of droplets by RT-PCR is not a generic marker of hygiene but can find specific application also in assessing environmental risks for other communicable diseases following an indirect rout of transmission, such as flu-like infections (Otter et al., 2016; Petersen, 2020; Wei et al., 2020).

Another limitation concerns the set of experimental conditions for RT-PCR and NGS. Primers and probes for selected bacterial genes from selected bacterial markers where chosen because of their 
medRxiv preprint doi: https://doi.org/10.1101/2020.08.22.20179754; this version posted August 25, 2020. The copyright holder for this preprint (which was not certified by peer review) is the author/funder, who has granted medRxiv a license to display the preprint in perpetuity.

All rights reserved. No reuse allowed without permission.

387 feasibility and effectiveness, but we did not made comparisons with different sequences, indicators

388 or reaction conditions for RT-PCR. The same concern can be raised for the NGS approach, which

389 was adopted for the analysis of 16S rDNA amplicon sequencing, following standard protocols. A

390 whole genome analysis would have been more informative. However, it would have also been

391 more expensive for materials and bioinformatic analysis, being less appropriate for public health

392 surveys on a larger scale. Finally, we used arbitrary thresholds to quantify droplets contamination

393 based on CT values, proposing the highest sensibility for droplets detection. A lower threshold

394 would have provided more specific data, or it could have been adapted to the different kind of

395 transmission risks or expected hygiene levels in the different environments.

398 Conclusions

399 Environmental monitoring of fomites with a potential role in COVID-19 transmission, can be

400 performed by RT-PCR. The general principle is based on the identification of anthropic

401 contaminations by detecting their microbiota component.

402 Droplets and biological fluids were observed in most of the indoor places exposed to human

403 presence, and on those surfaces frequently touched by hands. SARS-CoV-2 was not detectable

404 diffusely in the environment, except in the proximity of an infected patient and in consistent

405 association with fomites. The whole of the results supports the key role of handwashing and

406 environmental sanitation in reducing risks related to indirect transmission of COVID-19 in

407 hospitals or public areas, both indoor and outdoor. It also highlights the role of education and

408 awareness in protecting the health of all. 
medRxiv preprint doi: https://doi.org/10.1101/2020.08.22.20179754; this version posted August 25, 2020. The copyright holder for this preprint (which was not certified by peer review) is the author/funder, who has granted medRxiv a license to display the preprint in perpetuity.

All rights reserved. No reuse allowed without permission.

409 In addition to searching for SARS-CoV-2 in the environment, the possibility to detect fomites by

410 RT-PCR may provide a novel indicator for monitoring indirect transmission risks of COVID-19

411 as well as other communicable diseases transmitted through droplets, such as flu or flu-like

412 infections.

413

414 
medRxiv preprint doi: https://doi.org/10.1101/2020.08.22.20179754; this version posted August 25, 2020. The copyright holder for this preprint (which was not certified by peer review) is the author/funder, who has granted medRxiv a license to display the preprint in perpetuity.

All rights reserved. No reuse allowed without permission.

415

416

417

418

419

420

421

422

423

424

425

426

427

428

429

430

431

432

433

434

435

436

437

438

439

440

441

\section{Acknowledgments}

The authors would like to thank dr. Elena Scaramucci, Tiziana Zilli and Pietro Robert for supporting bibliography search and management; Alessandro Stabile for assuring laboratory safety and acceptance of reagents during summertime; the Copan Italia S.p.A. Brescia Italy for providing eNATand UTM collection kits. This study was partially supported by University of Foro Italico Project (CDR2.TER012013) assigned to V.R.S.

\section{References}

Aboubakr, H.A., Sharafeldin, T.A., Goya, S.M. 2020. Stability of SARS-CoV-2 and other coronaviruses in the environment and on common touch surfaces and the influence of climatic conditions: A review. Transbound Emerg Dis. 00:1-17 https://doi.org/10.1111/tbed.13707

Al Huraimel, K., Alhosani, M., Kunhabdulla, S., Stietiya, M. H. 2020. SARS-CoV-2 in the environment: Modes of transmission, early detection and potential role of pollutions. The Science of the total environment. 744, 140946. Advance online publication. https://doi.org/10.1016/j.scitotenv.2020.140946.

Arndt, D., Xia, J., Liu, Y., Zhou, Y., Guo, A.C., Cruz, J.A., Sinelnikov, I., Budwill, K., Nesbø, C.L., Wishart, D.S. 2012. METAGENassist: a comprehensive web server for comparative metagenomics. Nucleic Acids Res. 40, 88-95. https://doi.org/10.1093/nar/gks497

Asadi S, Wexler AS, Cappa CD, Barreda S, Bouvier NM, Ristenpart WD. 2020. Effect of voicing and articulation manner on aerosol particle emission during human speech. PLoS One;15(1): e0227699. doi: 10.1371/journal.pone.0227699. eCollection 2020.

Biryukov, J., Boydston, J.A., Dunning, R.A., Yeager, J.J, Wood, S., Reese, A.L., Ferris, Q., Miller, D., Weaver, W., Zeitouni, N.E., Phillips,A., Freeburger, D., Hooper, I., RatnesarShumate. S., Yolitz, J., Krause, M., Williams, G., Dawson, D.G., Herzog, A., Dabisch, P., Wahl, V., Hevey, M.C., Altamura, L.A. 2020. Increasing Temperature and Relative Humidity Accelerates Inactivation of SARS-CoV-2 on Surfaces. mSphere. 5(4):e00441-20. Published 2020 Jul 1. https://doi.org/10.1128/mSphere.00441-20 
442

443

444

445

446

447

448

449

450

451

452

453

454

455

456

457

458

459

460

461

462

463

464

465

466

467

468

469

470

471

Byrd, A.L., Belkaid,Y., Segre, J.A. 2018. The human skin microbiome. Nature Reviews Microbiology. 16,143ї 155. https://doi.org/10.1038/nrmicro.2017.157.

CDC, Centers for Disease Control and Prevention. 2020. CDC 2019-novel coronavirus (2019$\mathrm{nCoV}$ ) real-time RT-PCR diagnostic panel services. Centers for Disease Control and Prevention, Atlanta, GA. https://www.fda.gov/media/134922/download (access 10 August 2020).

Charles, D. D., Fisher, J. R., Hoskinson, S. M., Medina-Colorado, A. A., Shen, Y. C., Chaaban, M. R., Widen, S. G., Eaves-Pyles, T. D., Maxwell, C. A., Miller, A. L., Popov, V. L., \& Pyles, R. B. 2019. Development of a Novel ex vivo Nasal Epithelial Cell Model Supporting Colonization with Human Nasal Microbiota. Frontiers in cellular and infection microbiology. 9, 165. https://doi.org/10.3389/fcimb.2019.00165.

Chen, Y., Chen, L., Deng, Q., Zhang, G., Wu, K., Ni, L., Yang, Y., Liu, B., Wang, W., Wei, C., Yang, J., Ye, G., \& Cheng, Z. 2020. The presence of SARS-CoV-2 RNA in the feces of COVID19 patients. Journal of medical virology. 92(7), 833ї 840. https://doi.org/10.1002/jmv.25825.

Cheng, V.C.C., Wong, S.C., Chan, V.W.M., So, S.Y.C., Chen, J.H.K., Yip, C.C.Y., Chan, K.H., Chu, H., Chung, T.W.H., Sridhar, S., To, K.K.W., Chan, J.F.W., Hung, I.F.N., Ho, P.L., Yuen, K.Y. Air and environmental sampling for SARS-CoV-2 around hospitalized patients with coronavirus disease 2019 (COVID-19). Infect Control Hosp Epidemiol. 1-32.

https://doi.org/10.1017/ice.2020.2822020.

Chia, P.Y., Coleman, K.K., Tan, Y.K., Ong, S.W.X., Gum, M., Lau, S.K., Lim, X.F., Lim, A.S., Sutjipto, S., Lee, P.H., Son, T.T., Young, B.E., Milton, D.K., Gray, G.C., Schuster, S., Barkham, T., De, P.P., Vasoo S., Chan, M., Ang, B.S.P., Tan, B.H., Leo,Y.S., Ng, O.T., Wong, M.S.Y., Marimuthu, K., and for the Singapore 2019 Novel Coronavirus Outbreak Research Team. 2020. Detection of air and surface contamination by SARS-CoV-2 in hospital rooms of infected patients. Nat Comm. 11(1), 1-7. https://doi.org/10.1038/s41467-020-16670-2.

Colwell, R.K., Chao, A., Gotelli, N.J., Lin, S.Y., Mao, C.X., Chazdon, R.L., Longino, J.T. 2012. Models and estimators linking individual-based and sample-based rarefaction, extrapolation, and comparison of assemblages. Journal of Plant Ecology. 5, 3-21. https://doi.org/10.1093/jpe/rtr044.

Corman VM, Landt O, Kaiser M, Molenkamp R, Meijer A, Chu DK, Bleicker T, Brünink S, Schneider J, Schmidt ML, Mulders DG, Haagmans BL, van der Veer B, van den Brink S, Wijsman L, Goderski G, Romette JL, Ellis J, Zambon M, Peiris M, Goossens H, Reusken C, 
472 Koopmans MP, Drosten C. 2020. Detection of 2019 novel coronavirus (2019-nCoV) by real-

473 time RT-PCR. Euro surveillance: European communicable disease bulletin, 25(3), 2000045.

474 https://doi.org/10.2807/1560-7917.ES.2020.25.3.2000045.

475 Di Maria, F., Beccaloni, E., Bonadonna, L., Cini, C., Confalonieri, E., La Rosa, G., Milana, M.

476 R., Testai, E., Scaini, F. 2020. Minimization of spreading of SARS-CoV-2 via household waste

477 produced by subjects affected by COVID-19 or in quarantine. The Science of the total

478 environment, 743, 140803. Advance online publication.

479 https://doi.org/10.1016/j.scitotenv.2020.140803.

480 Esberg, A., Haworth, S., Kuja-Halkola, R., Magnusson, P., \& Johansson, I. 2020. Heritability of

481 Oral Microbiota and Immune Responses to Oral Bacteria. Microorganisms. 8(8), E1126.

482 https://doi.org/10.3390/microorganisms8081126.

483 Eslami, H., Jalili, M. 2020. The role of environmental factors to transmission of SARS-CoV-2

484 (COVID-19). AMB Express. 10(1), 92. https://doi.org/10.1186/s13568-020-01028-0

485 Farfour, E., Lesprit, P., Visseaux, B., Pascreau, T., Jolly, E., Houhou, N., Mazaux, L., Asso-

486 Bonnet, M., Vasse, M., \& SARS-CoV-2 Foch Hospital study group. 2020. The Allplex 2019-

$487 \mathrm{nCoV}$ (Seegene) assay: which performances are for SARS-CoV-2 infection diagnosis? European

488 journal of clinical microbiology \& infectious diseases: official publication of the European

489 Society of Clinical Microbiology, 10.1007/s10096-020-03930-8. Advance online publication.

490 https://doi.org/10.1007/s10096-020-03930-8.

491 Foladori, P., Cutrupi, F., Segata, N., Manara, S., Pinto, F., Malpei, F., Bruni, L., La Rosa, G.

492 2020. SARS-CoV-2 from faeces to wastewater treatment: What do we know? A review. The

493 Science of the total environment. 743, 140444. Advance online publication.

494

https://doi.org/10.1016/j.scitotenv.2020.140444.

495 Giampaoli, S., Alessandrini, F., Berti, A., Ripani, L., Choi, A., Crab, R., De Vittori, E., Egyed,

496 B., Haas, C., Lee, H. Y., Korabecná, M., Noel, F., Podini, D., Tagliabracci, A., Valentini, A., \&

497 Romano Spica, V. 2014. Forensic interlaboratory evaluation of the ForFLUID kit for vaginal

498 fluids identification. Journal of forensic and legal medicine. 21, $60 \ddot{1} 63$.

499 https://doi.org/10.1016/j.jflm.2013.10.016.

500 Giampaoli, S., Berti, A., Valeriani, F., Gianfranceschi, G., Piccolella, A., Buggiotti, L., Rapone, 501 C., Valentini, A., Ripani, L., \& Romano Spica, V. 2012. Molecular identification of vaginal fluid 
502

503

504

505

506

507

508

509

510

511

512

513

514

515

516

517

518

519

520

521

522

523

524

525

526

527

528

529

530

531

by microbial signature. Forensic science international. Genetics. 6(5), 559 ï 564.

https://doi.org/10.1016/j.fsigen.2012.01.005.

Guo, Z.D., Wang, Z.Y., Zhang, S.F., Li, X., Li, L., Li, C., Cui, Y., Fu, R.B., Dong, Y.Z., Chi, X.Y., Zhang, M.Y., Liu, K., Cao, C., Liu, B., Zhang, K., Gao, Y.W., Lu, B., Chen, W. 2020. Aerosol and Surface Distribution of Severe Acute Respiratory Syndrome Coronavirus 2 in Hospital Wards, Wuhan, China, 2020. Emerg Infect Dis. 26(7). doi.org/10.3201/eid2607.200885 Hung IF, Cheng VC, Li X, Tam AR, Hung DL, Chiu KH, Yip CC, Cai JP, Ho DT, Wong SC, Leung SS, Chu MY, Tang MO, Chen JH, Poon RW, Fung AY, Zhang RR, Yan EY, Chen LL, Choi CY, Leung KH, Chung TW, Lam SH, Lam TP, Chan JF, Chan KH, Wu TC, Ho PL, Chan JW, Lau CS, To KK, Yuen KY. 2020. SARS-CoV-2 shedding and seroconversion among passengers quarantined after disembarking a cruise ship: a case series. The Lancet. Infectious diseases, S1473-3099(20)30364-9. Advance online publication. https://doi.org/10.1016/S14733099(20)30364-9.

Kampf, G., Todt, D., Pfaender, S., Steinmann, E. 2020. Persistence of coronaviruses on inanimate surfaces and their inactivation with biocidal agents. The Journal of hospital infection. 104(3), 246ї 251. https://doi.org/10.1016/j.jhin.2020.01.022.

Kong, Y. 2011. Btrim: a fast, lightweight adapter and quality trimming program for nextgeneration sequencing technologies. Genomics. 98(2), 152-153.

https://doi.org/10.1016/j.ygeno.2011.05.009.

Lee, Y. M., Kim, Y. J., Kim, D. Y., Park, K. H., Lee, M.S. 2020. Monitoring environmental contamination caused by SARS-CoV-2 in a healthcare facility by using adenosine triphosphate testing. American journal of infection control, S0196-6553(20)30631-3. Advance online publication. https://doi.org/10.1016/j.ajic.2020.06.207.

Li, H.Y., Fan, Y.Z., Jiang, L., Wang, H.B. 2020. Aerosol and environmental surface monitoring for SARS-Cov-2 RNA in a designated hospital for severe COVID-19 patients. Epidemiology and Infection, 148, e154, 1-5. https://doi.org/10.1017/S0950268820001570.

Liu, Q., Liu, Q., Meng, H., Lv, H., Liu, Y., Liu, J., Wang, H., He, L., Qin, J., Wang, Y., Dai, Y., Otto, M., Li, M. 2020. Staphylococcus epidermidis Contributes to Healthy Maturation of the Nasal Microbiome by Stimulating Antimicrobial Peptide Production. Cell host \& microbe. 27(1), 68ї 78.e5. https://doi.org/10.1016/j.chom.2019.11.003. 
Liu, Y., Ning, Z., Chen, Y., Guo, M., Liu, Y., Gali, N. K., Sun, L., Duan, Y., Cai, J., Westerdahl, D., Liu, X., Xu, K., Ho, K. F., Kan, H., Fu, Q., \& Lan, K. 2020. Aerodynamic analysis of SARSCoV-2 in two Wuhan hospitals. Nature. 582(7813), 557-560. https://doi.org/10.1038/s41586020-2271-2273.

Lloyd-Price, J., Abu-Ali, G. \& Huttenhower, C. The healthy human microbiome. 2016. Genome Med 8, 51. https://doi.org/10.1186/s13073-016-0307-y.

Lv, J., Yang, J., Xue, J., Zhu, P., Liu, L., \& Li, S. 2020. Detection of SARS-CoV-2 RNA residue on object surfaces in nucleic acid testing laboratory using droplet digital PCR. The Science of the total environment, 742, 140370. Advance online publication.

https://doi.org/10.1016/j.scitotenv.2020.140370.

Magurran, A.E. Measuring biological diversity. Wiley-Blackwell: Oxford, UK; 2016.

Morawska L, Tang JW, Bahnfleth W, Bluyssen PM, Boerstra A, Buonanno G, Cao J, Dancer S, Floto A, Franchimon F, Haworth C, Hogeling J, Isaxon C, Jimenez JL, Kurnitski J, Li Y, Loomans M, Marks G, Marr LC, Mazzarella L, Melikov AK, Miller S, Milton DK, Nazaroff W, Nielsen PV, Noakes C, Peccia J, Querol X, Sekhar C, Seppänen O, Tanabe SI, Tellier R, Tham KW, Wargocki P, Wierzbicka A, Yao M. 2020. How can airborne transmission of COVID-19 indoors be minimised? Environment International, 142, 105832. https://doi.org/10.1016/j.envint.2020.105832

Mucci, N., Gianfranceschi, G., Cianfanelli, C., Santucci, S., Romano Spica, V., Valeriani, F. 2020. Can air microbiota be a novel marker for public health? A sampling model and preliminary data from different environments. Aerobiologia, 36 (1): 71-75.

NCIRD, National Center for Immunization and Respiratory Diseases (NCIRD). 2020. How COVID-19 spreads () https://www.cdc.gov/coronavirus/2019-ncov/about/transmission.html (accessed 10 August 2020)

Ong, S.W.X., Tan, Y.K., Chia, P.Y., Lee, T.H., Ng, O.T., Wong, M.S.Y., Marimuthu, K. 2020. Air, Surface Environmental, and Personal Protective Equipment Contamination by Severe Acute Respiratory Syndrome Coronavirus 2 (SARS-CoV-2) From a Symptomatic Patient. JAMA. 323(16):1610-1612. https://doi.org/10.1001/jama.2020.3227.

Otter, J. A., Donskey, C., Yezli, S., Douthwaite, S., Goldenberg, S. D., Weber, D. J. 2016. Transmission of SARS and MERS coronaviruses and influenza virus in healthcare settings: the 
562

563

564

565

566

567

568

569

570

571

572

573

574

575

576

577

578

579

580

581

582

583

584

585

586

587

588

possible role of dry surface contamination. The Journal of hospital infection. 92(3), $235 \mathrm{I} 250$. https://doi.org/10.1016/j.jhin.2015.08.027.

Pasquarella, C., Colucci, M. E., Bizzarro, A., Veronesi, L., Affanni, P., Meschi, T., Brianti, E., Vitali, P., \& Albertini, R. 2020. Detection of SARS-CoV-2 on hospital surfaces. Acta bio-medica Atenei Parmensis, 91(9-S), 76ï 78. https://doi.org/10.23750/abm.v91i9-S.10137.

Petersen, E., Koopmans,M., Go, U., Hamer, D.H., Petrosillo, N., Castelli, F., Storgaard, M., Al Khalili, S., Simonsen,L. 2020. Comparing SARS-CoV-2 with SARS-CoV and influenza pandemics Lancet Infect Dis. https://doi.org/10.1016/S1473-3099(20)30484-9.

Proctor, L., Lo Tempio, J., Marquitz, A., Daschner, P., Xi, D., Flores, R., Brown, L., Ranallo, R., Maruvada, P., Regan, K., Lunsford, R.D., Reddy, M., Caler, L. 2019. A review of 10 years of human microbiome research activities at the US National Institutes of Health, Fiscal Years 20072016. Microbiome 7, 31. https://doi.org/10.1186/s40168-019-0620-y.

Ratnesar-Shumate, S., Williams, G., Green, B., Krause, M., Holland, B., Wood, S., Bohannon, J., Boydston, J., Freeburger, D., Hooper, I., Beck, K., Yeager, J., Altamura, LA., Biryukov, J., Yolitz, J., Schuit, M., Wahl, V., Hevey, M., Dabisch, P. 2020. Simulated sunlight rapidly inactivates SARS-COV-2 on surfaces. J Infect Dis. 222(2):214-222.

https://doi.org/10.1093/infdis/jiaa274.

Razzini, K., Castrica, M., Menchetti, L., Maggi, L., Negroni, L., Orfeo, N. V., Pizzoccheri, A., Stocco, M., Muttini, S., Balzaretti, C. M. 2020. SARS-CoV-2 RNA detection in the air and on surfaces in the COVID-19 ward of a hospital in Milan, Italy. The Science of the total environment, 742, 140540. Advance online publication. https://doi.org/10.1016/j.scitotenv.2020.140540.

Segre, J.A. 2013. What does it take to satisfy Kochôs postulates two centuries later? Microbial genomics and Propionibacteria acnes. J Invest Dermatol. 133(9), 2141 ï 2142.

https://doi.org/10.1038/jid.2013.260

Slatko BE, Gardner AF, Ausubel FM. 2018. Overview of Next-Generation Sequencing Technologies. Curr Protoc Mol Biol. 2018 Apr;122(1):e59. https://doi.org/10.1002/cpmb.59. 
Somsen, G. A., van Rijn, C., Kooij, S., Bem, R. A., \& Bonn, D. 2020. Small droplet aerosols in poorly ventilated spaces and SARS-CoV-2 transmission. The Lancet. Respiratory medicine, 8(7), 658-659. https://doi.org/10.1016/S2213-2600(20)30245-9.

Stadnytskyi, V., Bax, C. E., Bax, A., \& Anfinrud, P. 2020. The airborne lifetime of small speech droplets and their potential importance in SARS-CoV-2 transmission. Proceedings of the National Academy of Sciences of the United States of America. 117(22), 11875-11877. https://doi.org/10.1073/pnas.2006874117.

Valeriani, F., Protano, C., Gianfranceschi, G., Cozza, P., Campanella, V., Liguori, G., Vitali, M., Divizia, M., Romano Spica, V. 2016. Infection control in healthcare settings: perspectives for mfDNA analysis in monitoring sanitation procedures. BMC infectious diseases. 16, 394. https://doi.org/10.1186/s12879-016-1714-9.

Valeriani, F., Agodi, A., Casini, B., Cristina, M. L., D'Errico, M. M., Gianfranceschi, G., Liguori, G., Liguori, R., Mucci, N., Mura, I., Pasquarella, C., Piana, A., Sotgiu, G., Privitera, G., Protano, C., Quattrocchi, A., Ripabelli, G., Rossini, A., Spagnolo, A. M., Tamburro, M., Romano Spica, V., GISIO Working Group of the Italian Society of Hygiene, Preventive Medicine, and Public Health. 2018a. Potential testing of reprocessing procedures by real-time polymerase chain reaction: A multicenter study of colonoscopy devices. American journal of infection control. 46(2), 159ï 164. https://doi.org/10.1016/j.ajic.2017.08.008.

Valeriani, F., Crognale, S., Protano, C., Gianfranceschi, G., Orsini, M., Vitali, M., Romano Spica, V. 2018b. Metagenomic analysis of bacterial community in a travertine depositing hot spring. The new microbiologica, 41(2), $126 і ̈ 135$.

Valeriani, F., Protano, C., Gianfranceschi, G., Leoni, E., Galasso, V., Mucci, N., Romano Spica, V. 2018c. Microflora Thermarum Atlas project: Biodiversity in thermal spring waters and natural SPA pools. Water Science and Technology: Water Supply. 18: $1472 і ̈ 1483$.

Valeriani, F., Margarucci, L. M., Gianfranceschi, G., Ciccarelli, A., Tajani, F., Mucci, N., Ripani, M., \& Romano Spica, V. 2019. Artificial-turf surfaces for sport and recreational activities: microbiota analysis and $16 \mathrm{~S}$ sequencing signature of synthetic vs natural soccer fields. Heliyon, 5(8), e02334. https://doi.org/10.1016/j.heliyon.2019.e02334.

Van Doremalen, N., Bushmaker, T., Morris, D.H., Holbrook, M.G., Gamble, A., Williamson, B.N., Tamin, A., Harcourt, J.L., Thornburg, N.J., Gerber, S.I., Lloyd-Smith, J.O., de Wit,E., 
medRxiv preprint doi: https://doi.org/10.1101/2020.08.22.20179754; this version posted August 25, 2020. The copyright holder for this preprint (which was not certified by peer review) is the author/funder, who has granted medRxiv a license to display the preprint in perpetuity.

All rights reserved. No reuse allowed without permission.

619

620

621

622

623

624

625

626

627

628

629

630

631

632

633

634

635

636

637

638

639

640

641

642

643

644

645

646

647

648

Munster, V.J. 2020. Aerosol and surface stability of SARS-CoV-2 as compared with SARSCoV-1. N Engl J Med. 382, 1564-1567. https://doi.org/10.1056/NEJMc2004973.

Veronesi, L., Colucci, M.E., Pasquarella, C., Caruso, L., Mohieldin Mahgoub Ibrahim, M., Zoni, R., Pergreffi, M., Arcuri, C., Seidenari, C., Viani, I., Capobianco, E., Mezzetta, S., Affanni, P. 2020. Virological surveillance of SARS-CoV-2 in an Italian northern area: comparison of Real Time RT PCR cycle threshold $(\mathrm{Ct})$ values in three epidemic periods. Acta Biomed. $2020 \mathrm{Jul}$ 20;91(9-S):19-21. https://doi.org/10.23750/abm.v91i9-S.10138.

Wang, J., Feng, H., Zhang, S., Ni, Z., Ni, L., Chen, Y., Zhuo, L., Zhong, Z., \& Qu, T. 2020. SARS-CoV-2 RNA detection of hospital isolation wards hygiene monitoring during the Coronavirus Disease 2019 outbreak in a Chinese hospital. International journal of infectious diseases: IJID: official publication of the International Society for Infectious Diseases. 94, 103ї 106. https://doi.org/10.1016/j.ijid.2020.04.024.

Wei, L., Lin, J., Duan, X., Huang, W., Lu, X., Zhou, J., Zong, Z. 2020. Asymptomatic COVID19 Patients Can Contaminate Their Surroundings: An Environment Sampling Study. mSphere. 5(3), e00442-20. https://doi.org/10.1128/mSphere.00442-20.

WHO, World Health Organization. 2020. Transmission of SARS-CoV-2: implications for infection prevention precautions. Scientific Brief. https://www.who.int/newsroom/commentaries/detail/transmission-of-sars-cov-2-implications-for-infection-preventionprecautions (accessed 10 August 2020).

WHO, World Health Organization. Infection Prevention and Control of Epidemic-and Pandemicprone Acute Respiratory Infections in Health Care. Geneva: World Health Organization; 2014 https://apps.who.int/iris/bitstream/handle/10665/112656/9789241507134_eng.pdf;jsessionid=41 AA684FB64571CE8D8A453C4F2B2096? sequence=1 (access 10 August 2020).

Wu, S., Wang, Y., Jin, X., Tian, J., Liu, J., Mao, Y. 2020. Environmental contamination by SARS-CoV-2 in a designated hospital for coronavirus disease 2019. American journal of infection control. 48(8), 910ї 914. https://doi.org/10.1016/j.ajic.2020.05.003.

Yao, T., Han, X., Guan, T., Wang, Z., Zhang, S., Liu, C., Liu, C., Chen, L. 2020. Effect of indoor environmental exposure on seminal microbiota and its application in body fluid identification. Forensic science international. 314, 110417. Advance online publication. https://doi.org/10.1016/j.forsciint.2020.110417. 
medRxiv preprint doi: https://doi.org/10.1101/2020.08.22.20179754; this version posted August 25, 2020. The copyright holder for this preprint (which was not certified by peer review) is the author/funder, who has granted medRxiv a license to display the preprint in perpetuity.

All rights reserved. No reuse allowed without permission. 
medRxiv preprint doi: https://doi.org/10.1101/2020.08.22.20179754; this version posted August 25, 2020. The copyright holder for this preprint (which was not certified by peer review) is the author/funder, who has granted medRxiv a license to display the preprint in perpetuity.

All rights reserved. No reuse allowed without permission.

Table 1

\begin{tabular}{|c|c|c|c|c|c|c|}
\hline \multirow{2}{*}{$\begin{array}{l}\text { Classification } \\
\text { Surface source }\end{array}$} & \multirow[b]{2}{*}{ Samples } & \multirow{2}{*}{$\begin{array}{c}\text { Dataset } \\
(\mathrm{N}=94)\end{array}$} & \multirow[b]{2}{*}{ Description } & \multicolumn{3}{|c|}{ Nucleic Acid Testing } \\
\hline & & & & $\begin{array}{l}\text { SARS- } \\
\text { CoV-2 }\end{array}$ & $\begin{array}{c}\text { Biofluid } \\
\text { (RT-PCR) }\end{array}$ & $\begin{array}{c}\text { Microbiota } \\
(\mathrm{NGS})\end{array}$ \\
\hline \multirow{26}{*}{ Indoor } & \multirow{18}{*}{ Hospital } & \multirow{18}{*}{49} & Floor $(\mathrm{n}=7)$ & + & + & + \\
\hline & & & Bedside table $(\mathrm{n}=3)$ & + & + & + \\
\hline & & & Door handle $(\mathrm{n}=3)$ & + & + & + \\
\hline & & & Call button $(\mathrm{n}=1)$ & + & + & + \\
\hline & & & Table $(\mathrm{n}=1)$ & + & + & + \\
\hline & & & Chair $(n=2)$ & + & + & + \\
\hline & & & Back of the bed $(n=3)$ & + & + & + \\
\hline & & & Side of bed $(n=4)$ & + & + & + \\
\hline & & & Bottom of the bed $(n=1)$ & + & + & + \\
\hline & & & Wall behind the bed head $(n=1)$ & + & + & + \\
\hline & & & Bed sheets $(\mathrm{n}=1)$ & + & + & + \\
\hline & & & Pillow $(\mathrm{n}=2)$ & + & + & + \\
\hline & & & Stethoscope $(\mathrm{n}=1)$ & + & + & + \\
\hline & & & Wheelchair head $(\mathrm{n}=1)$ & + & + & + \\
\hline & & & Toilet board $(\mathrm{n}=1)$ & + & + & + \\
\hline & & & Toilet flush button $(\mathrm{n}=1)$ & + & + & + \\
\hline & & & Sink faucet $(\mathrm{n}=1)$ & + & + & + \\
\hline & & & Air circulation system (15) & + & - & - \\
\hline & \multirow{8}{*}{$\begin{array}{l}\text { Public } \\
\text { Building }\end{array}$} & \multirow{8}{*}{25} & Door handle $(\mathrm{n}=2)$ & \pm & + & + \\
\hline & & & Toilet $(\mathrm{n}=2)$ & + & + & + \\
\hline & & & Pews $(n=4)$ & - & + & + \\
\hline & & & Floor $(n=6)$ & \pm & + & + \\
\hline & & & Toilet wall tiles $(n=3)$ & \pm & + & + \\
\hline & & & Office phone $(\mathrm{n}=1)$ & + & + & + \\
\hline & & & Computer keyboard $(\mathrm{n}=2)$ & + & + & + \\
\hline & & & Air circulation system $(n=5)$ & - & + & + \\
\hline \multirow{6}{*}{ Outdoor } & & \multirow{6}{*}{16} & Handrail $(\mathrm{n}=1)$ & + & + & + \\
\hline & & & Grip shared e-scouter $(\mathrm{n}=1)$ & + & + & + \\
\hline & & & Bus stop bench $(\mathrm{n}=1)$ & + & + & + \\
\hline & & & Coffee dispenser button $(n=1)$ & + & + & + \\
\hline & & & External door handle $(\mathrm{n}=2)$ & \pm & + & + \\
\hline & & & Playground $(\mathrm{n}=10)$ & - & \pm & + \\
\hline Human & & 4 & Dropletsôbiofluid (n=4) & \pm & + & + \\
\hline
\end{tabular}

Table 1. Environmental sampling: dataset of collected samples and testing. Indoor surfaces were sampled from different hospitals $(n=3)$, buildings of public use (1 office, 1 Fast food, 1 church), outdoor areas $(n=16)$, nose-oropharyngeal secretions $(n=4)$ and tested for presence of SARS-CoV-2 and for anthropic contamination by testing the presence of microbiota traces of biological fluids (Nose, Saliva, Feces), by Real Time PCR (RT-PCR) and/or Next Generation Sequencing (NGS). For each type of test,

657 analysis was performed in all $(+)$, no one $(-)$ or some $( \pm)$ of the collected samples. 
Table 2

\section{ANTROPIC CONTAMINATION FROM BIOFLUIDSÔMICROBIOTA}

\begin{tabular}{|c|c|c|c|c|c|c|}
\hline \multirow[b]{2}{*}{ Sample source } & \multirow[b]{2}{*}{ Code } & \multirow[b]{2}{*}{ Skin } & \multicolumn{2}{|c|}{ Droplets } & \multirow[b]{2}{*}{ Feces } & \multirow[b]{2}{*}{ Sample description } \\
\hline & & & Nasopharynx & Oropharynx & & \\
\hline \multirow{4}{*}{ Controls $(n=4)$} & A_01 & - & +++ & - & - & Dropletsôbiofluid \\
\hline & A_02 & ++++ & +++++ & + & - & Dropletsôbiofluid \\
\hline & A_03 & ++++ & +++++ & ++ & - & Dropletsôbiofluid \\
\hline & A_04 & ++++ & ++++++ & + & - & Droplets ôiofluid \\
\hline \multirow{6}{*}{ Outdoor $(n=6)$} & Z_01 & +++ & +++ & - & + & Handrail \\
\hline & Z_02 & $+/-$ & + & - & - & Bus stop bench \\
\hline & Z_03 & ++ & ++ & - & $+/-$ & Shared e-scouter grip \\
\hline & Z_04 & - & + & - & - & External door handle \\
\hline & Z_05 & ++ & + & - & $+/-$ & External door handle \\
\hline & Z_06 & ++ & + & - & - & Coffee dispenser \\
\hline \multirow{28}{*}{ Indoor $(n=55)$} & YH1_01 & +++ & ++ & + & + & Right bed rail* \\
\hline & YH1_02 & +++ & ++ & $+/-$ & $+/-$ & Bedside table \\
\hline & YH1_03 & ++ & +++ & ++++ & +++ & Door handle \\
\hline & YH1_04 & ++ & +++ & - & $+/-$ & Floor \\
\hline & YH1_05 & ++ & ++++ & + & +++ & Call button* \\
\hline & YH1_06 & ++ & ++ & - & - & Table \\
\hline & YH1_07 & - & ++ & - & - & Chair \\
\hline & YH1_08 & - & +++ & - & - & Back of the bed \\
\hline & YH1_09 & - & ++ & - & - & Air inlet socket \\
\hline & YH1_10 & +++ & ++ & +++ & - & Wall behind the bed \\
\hline & YH1_11 & +++ & +++ & +++ & ++ & Left bed rail \\
\hline & YH1_12 & - & +++ & - & - & Stethoscope* \\
\hline & YH1_13 & - & +++ & - & - & Bottom of the bed \\
\hline & YH1_14 & + & ++++ & - & $+/-$ & Wheelchair head \\
\hline & YH2_15 & ++++ & ++ & - & - & Pillow \\
\hline & YH2_16 & - & + & - & - & Chair \\
\hline & YH2_17 & - & + & - & - & Back of the bed \\
\hline & YH2_18 & - & $+/-$ & - & $+/-$ & Toilet board \\
\hline & YH2_19 & - & $+/-$ & - & + & Sink faucet \\
\hline & YH2_20 & - & ++ & - & - & Floor \\
\hline & YH2_21 & + & $+/-$ & - & - & Floor \\
\hline & YH2_22 & - & ++ & ++++ & - & Floor \\
\hline & YH2_23 & - & + & - & - & Door handle \\
\hline & YH2_24 & +++ & ++ & - & $+/-$ & Back of the bed \\
\hline & YH2_25 & ++ & + & ++++ & - & Side of bed \\
\hline & YH2_26 & + & + & - & +++ & Side of bed \\
\hline & YH2_27 & - & - & - & - & Bedside table \\
\hline & YH2_28 & - & $+/-$ & - & + & Bedside table \\
\hline
\end{tabular}




\section{ANTROPIC CONTAMINATION FROM BIOFLUIDSÔMICROBIOTA}

\begin{tabular}{|c|c|c|c|c|c|c|}
\hline \multirow[b]{2}{*}{ Sample source } & \multirow[b]{2}{*}{ Code } & \multirow[b]{2}{*}{ Skin } & \multicolumn{2}{|c|}{ Droplets } & \multirow[b]{2}{*}{ Feces } & \multirow[b]{2}{*}{ Sample description } \\
\hline & & & Nasopharynx & Oropharynx & & \\
\hline & YH2_29 & - & ++ & - & - & Pillow \\
\hline & YH2_30 & - & + & - & - & Bed sheets \\
\hline & YH2_31 & + & ++ & - & - & Floor \\
\hline & YH2_32 & - & ++ & - & - & Floor \\
\hline & YH2_33 & - & + & - & - & Floor \\
\hline & YH3_34 & ++++++ & ++++ & - & - & Toilet \\
\hline & YH3_35 & - & ++ & - & - & Toilet \\
\hline & YH3_36 & $+/-$ & - & - & - & Door handle \\
\hline & YC_37 & - & + & - & - & Pew and surface \\
\hline & YC_38 & - & + & - & - & Pew and surface \\
\hline & YC_39 & - & + & - & - & Pew and surface \\
\hline & YC_40 & ++ & ++++ & + & - & Pew and surface \\
\hline & YO_41 & - & - & - & + & Floor \\
\hline & YO_42 & - & - & $+/-$ & $+/-$ & Floor \\
\hline & YO_43 & - & - & - & + & Floor \\
\hline & YO_44 & - & - & - & + & Floor \\
\hline & YO_45 & - & - & - & - & Floor \\
\hline & YO_46 & - & - & - & + & Floor \\
\hline & YO_47 & - & - & - & $+/-$ & Toilet wall tiles \\
\hline & YO_48 & - & - & - & + & Toilet wall tiles \\
\hline & YO_49 & - & - & - & + & Toilet wall tiles \\
\hline & YO_50 & - & - & - & $+/-$ & Office phone \\
\hline & YO_51 & - & - & - & + & Computer Keyboard \\
\hline & YO_52 & $+/-$ & - & - & + & Computer Keyboard \\
\hline & YO_53 & + & + & + & + & Elevator handle \\
\hline & YO_54 & +++ & +++ & + & $+/-$ & Toilet door handle \\
\hline & YO_55 & ++ & ++ & - & - & Toilet flush button \\
\hline
\end{tabular}

Table 2. Anthropic contamination by Real Time PCR. The cumulative output of indicators for each anthropic contamination is shown, including the description of each sample. For each indicator: ñ+++ò Positive: Ct <20; ñ++ò Positive: Ct 20-30; ñ+ò Positive Ct 30-35; ñ+/-ò Doubt:

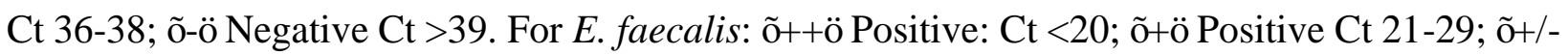
òDoubt: Ct 30-35; ñòNegative $\mathrm{Ct}>36$. The asterisk (*) shows the sampling points where SARS- 
Table 3

670

671

672

673

674

675

676

677

678

679

680

\begin{tabular}{|c|l|c|c|c|}
\hline \multicolumn{5}{|c|}{ RT-PCR Droplets' Markers } \\
\hline \multirow{2}{*}{ Origin } & \multicolumn{1}{|c|}{ Indicators } & $\mathbf{R C 1}$ & $\mathbf{R C 2}$ & $\mathbf{R C 3}$ \\
\hline \multirow{3}{*}{ Nasopharynx } & Propiniumbacterium spp & $\mathbf{0 . 9 3}$ & 0.05 & -0.01 \\
\cline { 2 - 5 } & Corynebacterium spp & $\mathbf{0 . 6 6}$ & -0.03 & 0.39 \\
\hline \multirow{3}{*}{ Oropharynx } & Streptococcus mutans & 0.21 & $\mathbf{0 . 7 6}$ & 0.11 \\
\cline { 2 - 5 } & Staphylococcus salivarius & 0.02 & $\mathbf{0 . 8 9}$ & -0.15 \\
\hline \multirow{2}{*}{ Nostril-skin } & Staphylococcus aureus & 0.06 & 0.30 & $\mathbf{0 . 8 0}$ \\
\cline { 2 - 5 } & Staphylococcus epidermidis & 0.13 & -0.07 & $\mathbf{0 . 8 8}$ \\
\hline
\end{tabular}

681

682 Table 3. Primary indicators for droplets. Pattern matrix for principal component analysis 683 nasopharynx selected indicators (Propiniumbacterium spp., Corynebacterium spp.), oropharynx 684 (Streptococcus mutans, Staphylococcus salivarius), of nostril-skin (Staphylococcus aureus, 685 Staphylococcus epidermidis). The higher correlations for each component (RC) are shown in bold 686 ( $\mathrm{p}<0.01)$. The table reported variable loading on the rotation matrix. 
Figure 1
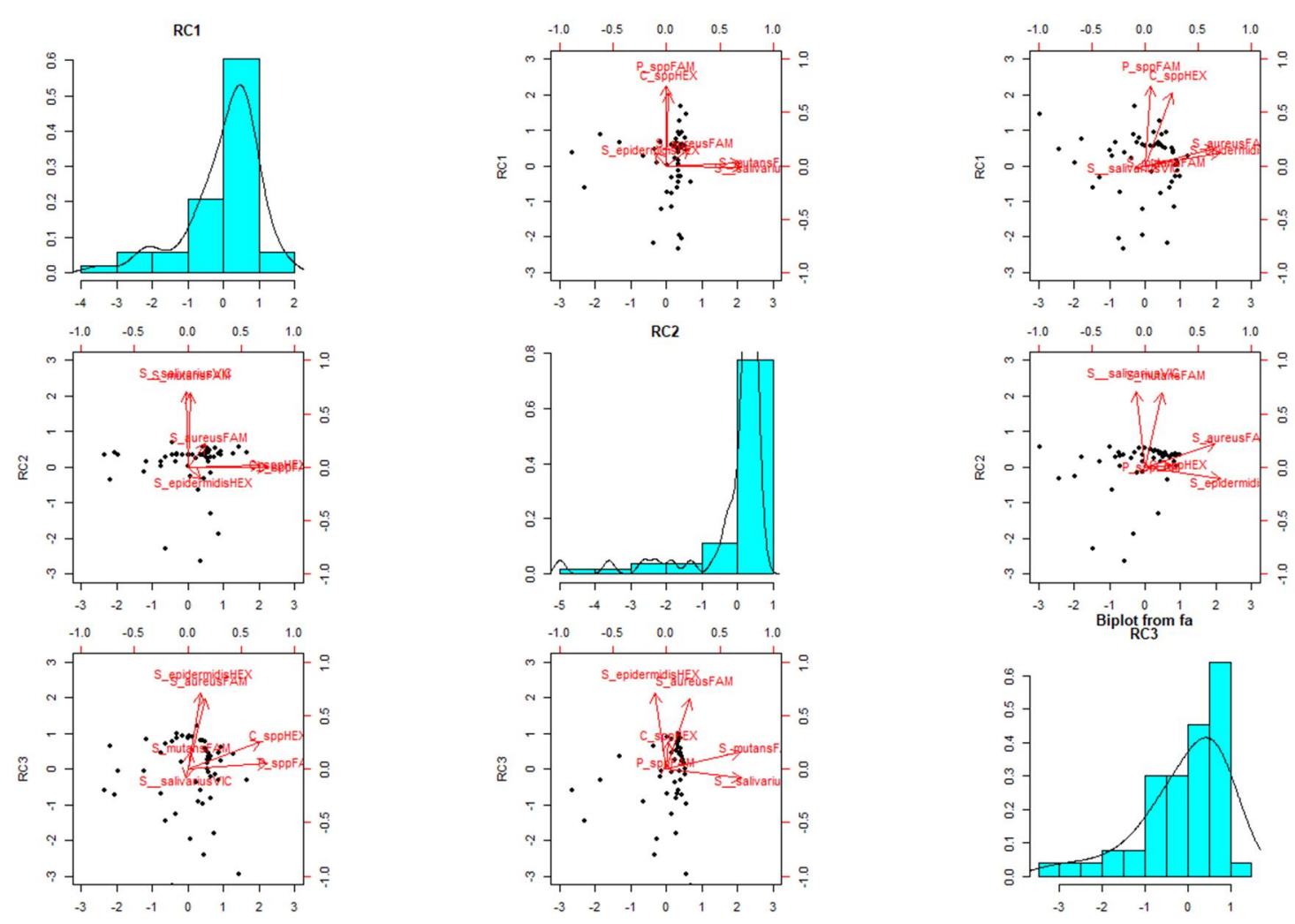

690

691

Figure 1. Dropletsôcomponentsôdistribution. Principal Component Analysis biplots showing 


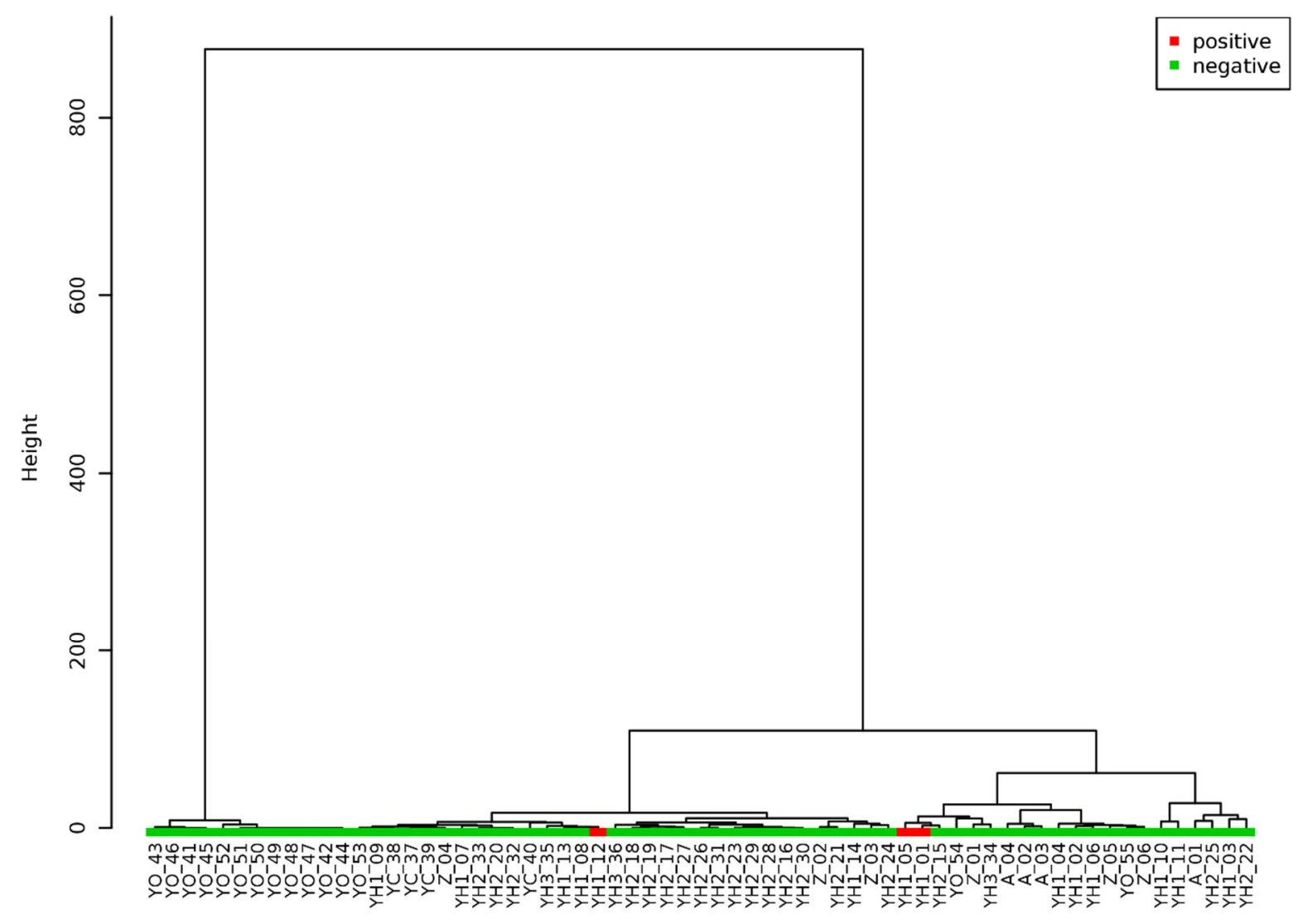
negative samples are indicated in green and red, respectively. The hierarchical cluster was performed on raw CT data by Euclidean distance and Ward's linkage (clustering to minimize the 706 sum of squares of any two clusters). 
Figure 3

\section{Cluster with ward method}

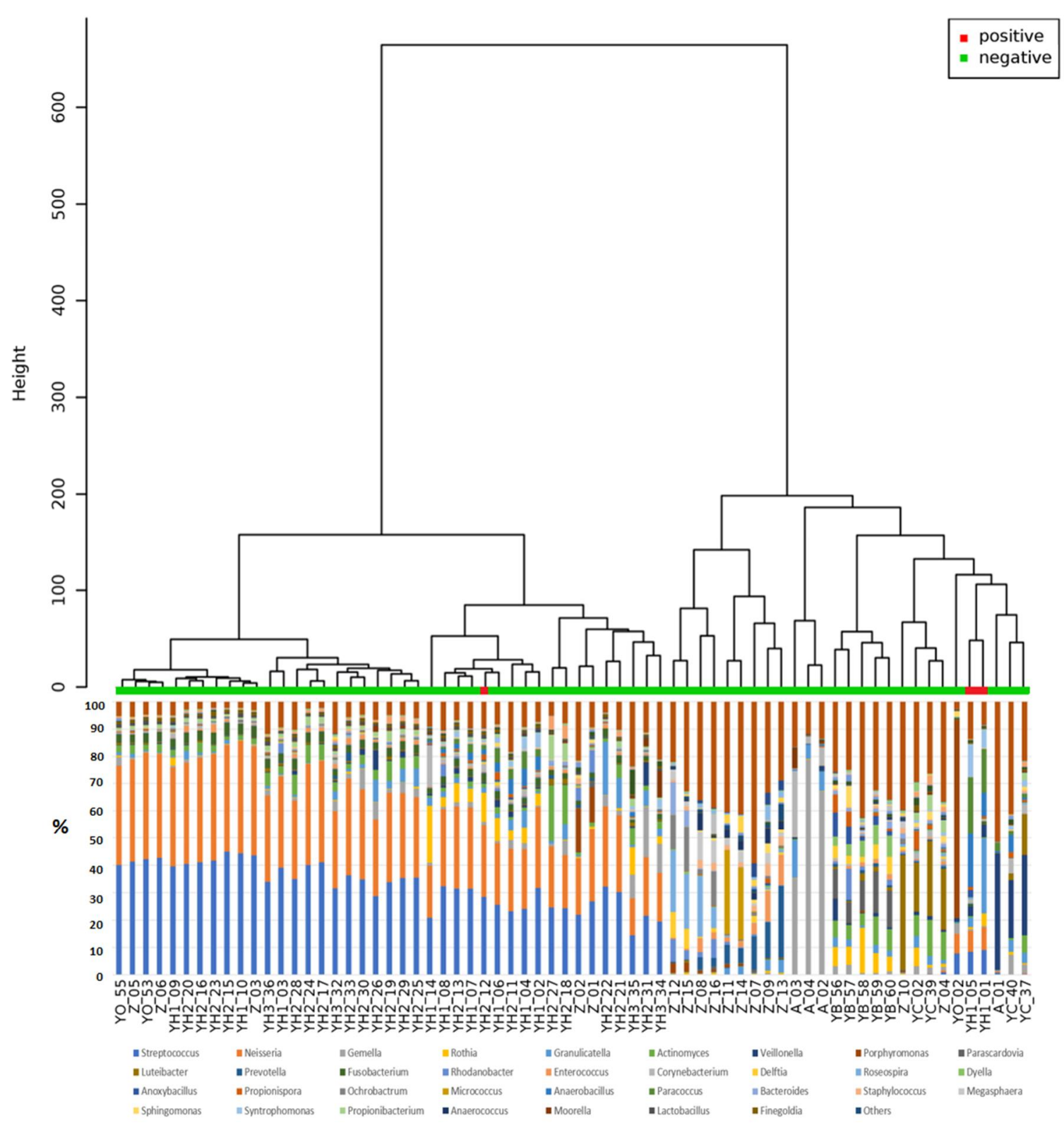

Figure 3. Hierarchical Clustering Dendrogram on $16 \mathrm{~S}$ amplicon sequencing data. bar chart under each sample summarizes the relative abundance of its genus-level classifications. In this analysis were included also environmental samples from playgrounds (Z_07-16) and indoor air (YB_56-60), without major anthropic contaminations. SARS-CoV-2 negative and positive samples are indicated in green and red, respectively. 


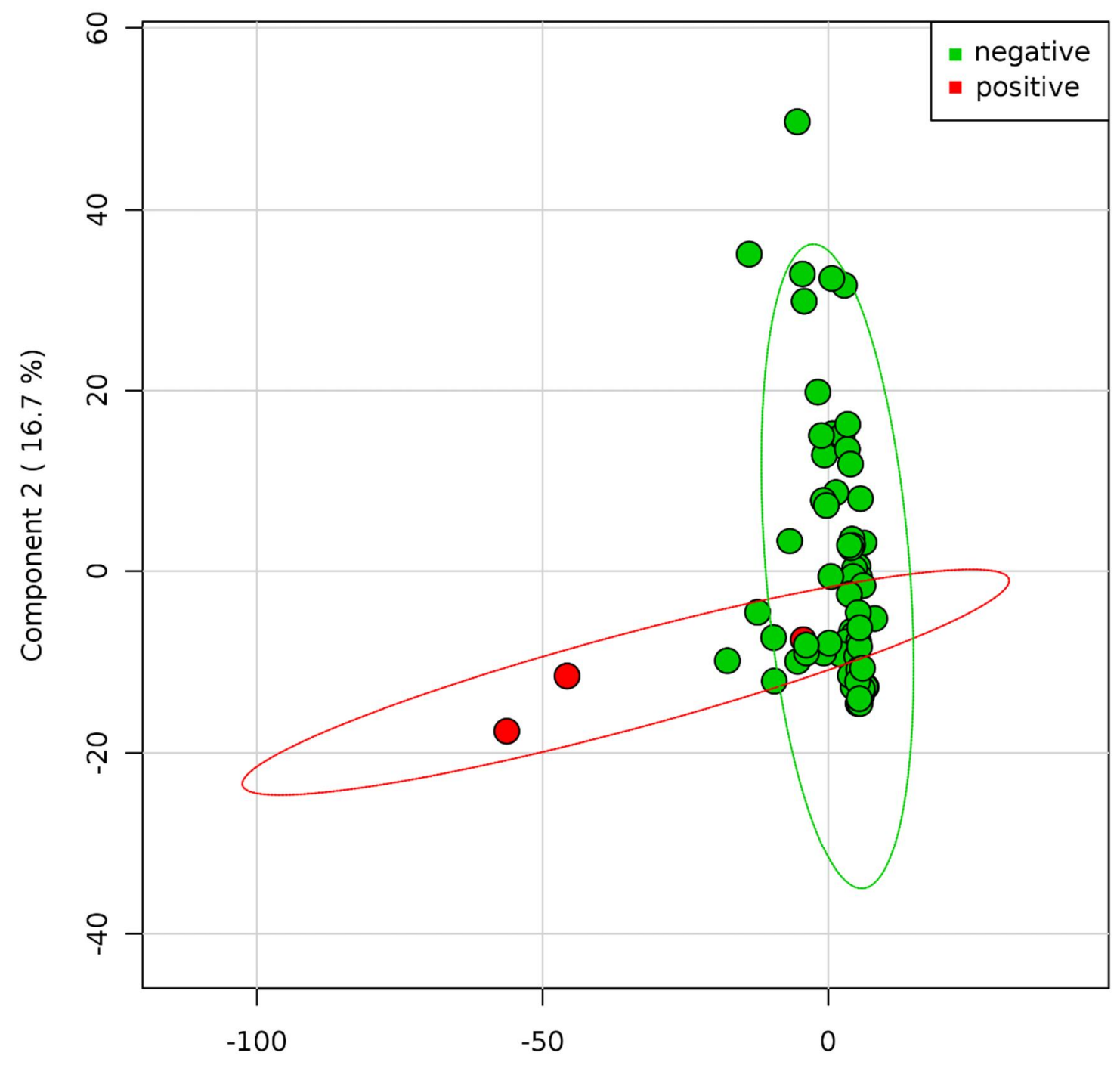

Component $1(6.6 \%)$

722 Figure 4. SARS-CoV-2 positive and negative samples. Principal Coordinate Analysis of the 723 normalized relative abundance of all samples divided by negative and positive results of SARS724 COV2. Data are plotted at the genus-level classification. The variance is explained for $6.6 \%$ and $72516.7 \%$, respectively for Component 1 and 2. SARS-CoV-2 positive (red) and negative (green) 726 samples. 


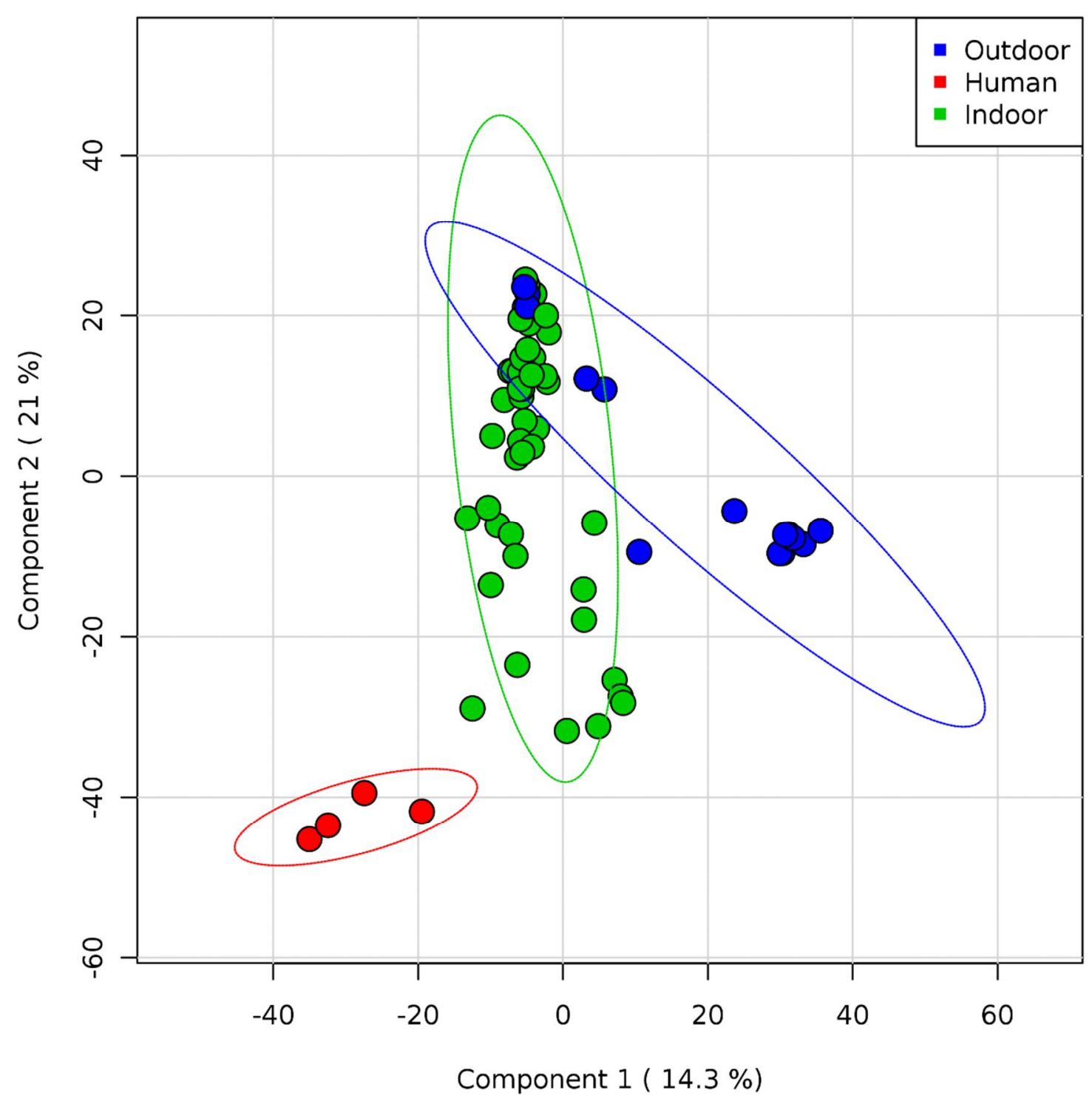

Figure 5. Whole microflora analysis of indoor and outdoor samples. Partial least squarediscriminant analysis (PLS-DA) shows Pearson distance between different samples using phylogeny distribution based on $16 \mathrm{~S}$ rRNA genes. Samples are colored according to the sampling point (red: human droplets; green: indoor; blue: outdoor). The variance is explained for $14.3 \%$ and $21 \%$, respectively for Component 1 and 2. Outdoor samples overlapping indoor samples are characterized by fomites, whereas the blue sample between groups is the outdoor handle of a building main entrance. All samples without a major presence of environmental microflora, but characterized by a prevalence of human microbiota from droplets biofluids, tend to segregate independently. 